\title{
MODEL PENGUATAN EKONOMI MASYARAKAT MELALUI JASA LES PRIVAT DAN NGAJI
}

\author{
As'ad Umar, ${ }^{1}$ Dwi Ari Pertiwi ${ }^{2}$ \\ ${ }^{1}$ Fakultas Ekonomi Universitas Hasyim Asy'ari Tebuireng \\ 1 umarasad81@gmail.com \\ 2dwi.unhasy@gmail.com
}

\begin{abstract}
Data from the Central Statistics Agency (BPS) Mojokerto notes that every year around eight hundred and five children do not continue their education. The contributing factors of this are (1) psychological factors, 2) family factors, and 3) economic factors. Al Farisi Smart House was established aiming to create a generation of young people who are smart, independent and have moral character. Al Farisi Smart House has two excellent programs, namely a free tutoring program for orphans and two students, and a program of 100 private tutors and the Koran. Free tutoring program specifically for elementary and junior high school students who are orphans. While the one hundred private tutoring and Koran program is aimed at fostering economically weak high school graduates who have good academic skills. This research method is qualitative research. The research objective is to determine the economic strengthening model through private tutoring and the Koran. The results of this study indicate that students in the Al Farisi smart home have increased. Indicators of improvement can be known through education indicators, food and drink fulfillment indicators, and vehicle indicators.
\end{abstract}

Keywords:Economic Strengthening, Private Les

\begin{abstract}
Abstrak: Data dari Badan Pusat Statistik (BPS) Mojokerto mencatat bahwa setiap tahun ada sekitar delapan ratus lima anak yang tidak melanjutkan sekolahnya. Faktor penyebabnya yaitu faktor psikologis, 2) faktor keluarga, dan 3) faktor ekonomi,. Rumah Cerdas Al Farisi didirikan bertujuan untuk menciptakan generasi muda yang cerdas, mandiri dan memiliki karakter moral. Rumah cerdas Al Farisi mempunyai dua program unggulan yaitu program les gratis bagi siswa yatim dan duafa, dan program 100 guru les privat dan ngaji. Program les gratis khusus untuk siswa SD dan SMP yang yatim. Sedangkan Program seratus guru les privat dan ngaji untuk membina para lulusan SMA yang lemah ekonomi, namun punya kemampuan yang baik secara akademik. Metode penelitian ini adalah penelitian kualitatif. Tujuan penelitian untuk mengetahui model penguatan ekonomi melalui jasa les privat dan ngaji. Hasil penelitia ini menunjukkan bahwa siswa binaan di rumah cerdas al Farisi mengalami peningkatan. Indikator peningkatan bisa diketahui melalui indikator pendidikan, indikator pemenuhan makan dan minum, dan indikator kendaraan. Kata kunci: Penguatan Ekonomi, Les Privat
\end{abstract}

\section{Pendahuluan}

Badan Pusat Statistik (BPS) Kabupaten Mojokerto mencatat bahwa setiap tahun ada sekitar delapan ratus lima anak yang tidak melanjutkan pendidikanyang lebih tinggi di Mojokerto. Senada dengan BPS Mojokerto, data Dinas Pendidikan Mojokerto hingga 2018 menyebutkan di Mojokerto lebih dari delapan ratus anak tidak sekolah, yang terdiri dari berbagai tingkatan pendidikan, mulai dari tingkat sekolah dasar/madrasah ibtidaiyah, yaitu 320 siswa tidak sekolah. Tingkat SMP/MTs ada 375 siswa yang tidak melanjutkan sekolah.Dan sisanya, tingkat SMA/SMK dan MA sebanyak 105 siswa. Beberapa faktor yang menjadi indikasi anak tidak sekolah di Mojokerto antara lain: 1) faktor psikologis, seperti kurangnya minat anak untuk bersekolah, disebabkan kesadaran dan motivasi diri yang kurang, 2) faktor keluarga, seperti keluarga yang tidak utuh, ayah dan ibu bercerai, dan 3) faktor ekonomi, seperti orang tua yang bekerja serabutan, menjadi buruh tani, buruh pabrik, pembantu rumah tangga, dengan penghasilan yang tidak mencukupi.

Kondisi ini tentu bertolak belakang dengan misi Kementerian Riset, Teknologi, dan Pendidikan Tinggi (Kemenristekdikti) Republik Indonesia saat ini, yakni mencetak generasi yang berilmu, mandiri, dan berwirausaha. Di samping juga bertentangan dengan Pembukaan UUD 1945 alinea 
keempat bahwa salah satu tujuan membentuk negara Republik Indonesia adalah untuk mencerdaskan kehidupan bangsa.

Salah satu tujuan pendirian Rumah Cerdas Al Farisi adalah mencetak generasi muda yang cerdas, mandiri dan berakhlaqul karimah, dan memberi kesempatan kepada anak bangsa mendapat pendidikan yang baikdan gratis.Dua program Rumah Cerdas yang menjadi unggulanyaitu program Les gratis bagi siswa yatim dan duafa', dan program seratus Guru Les Privat dan Ngaji'. Program les gratis dikhususkan bagi siswa SD/MI dan SMP yatim dan duafa. Sedangkan program seratus guru les privat dan ngaji bertujuan untuk membina para lulusan SMA sederajat yang lemah secara ekonomi, namun punya kemampuan secara akademik. Program seratus guru les privat dan ngaji ini dilakukan dengan memberikan pembinaan dan pelatihan pedagogik dan pembinaan Baca dan Tulis Al-Qur'an (BTQ). Pembinaan dan pelatihan ini diharapkan bisa menjadi pengalaman dan bekal yang cukup kepada mereka sebelum disalurkan menjadi guru les privat dan ngaji.

Penelitian ini bertujuan untuk mengetahui model penguatan ekonomi masyarakat melalui jasa les privat dan ngaji.

\section{Metode}

Metode penelitian ini adalah penelitian kualitatif, yaitu penelitian yang menghasilkan data deskriptif. Tujuan penelitian ini bukan untuk menguji, namun didasari oleh rasa ingin tahu penulis tentang model penguatan ekonomi masyarakat melalui jasa les privat dan ngaji.

Teknik pengumpulan data yang digunakan ada beberapa cara, antara lain:

1. Observasi, bertujuan menjawab masalah penelitian. Dalam hal ini yang peneliti lakukan adalah mendatangi langsung lokasi Rumah Cerdas Al Farisi di Lingkungan Sinoman Gg IV Kelurahan Miji Kecamatan Kranggan Mojokerto. Serta orang-orang yang mengikuti jasa les privat dan ngaji dalam upaya meningkatkan perekonomian masyarakat.

2. Wawancara, tujuan untuk mendapatkan informasi yang terkait denganmodel penguatan ekonomi melalui les privat dan ngaji di Rumah Cerdas Al Farisi di Mojokerto Jawa Timur. Dalam pelaksanaannya, peneliti mewawancarai langsung pihak-pihak yang ada dalam struktur kepengurusan Rumah Cerdas $\mathrm{Al}$ Farisi dan masyarakat yang mengikuti kegiatan jasa les privat dan ngaji

3. Dokomentasi, dilakukan untuk memperoleh data-data yang berkaitan dengan pelaksanaan program kelembagaan, seperti penguatan ekonomi melalui jasa les privat dan ngaji, dan data-data tentang sejarah lembaga itu sendiri serta data-data lain yang berhubungan dengan pokok penelitian. Adapun sifat dokumen yang dibutuhkan dalam penelitian ini adalah dokomen resmi internal.

\section{Hasil dan Pembahasan}

Rumah Cerdas Al Farisi adalah lembaga bimbingan belajar yang berada dalam naungan Yayasan Pendidikan dan Sosial Al Majid Mojokerto. Dalam pelaksanaannya program Rumah cerdas $\mathrm{Al}$ Farisi mempunyai dua program unggulan yaitu program les gratis bagi siswa yatim dan duafa, dan program 100 guru les privat dan ngaji. Program les gratis di Rumah Cerdas Al Farisi khususkan untuk siswa SD/ MI dan SMP/Mts yang yatimdan duafa', dan diharapkan bisa memberikan kesempatan mereka mendapatkan pendidikan/ les yang baik dan gratis, yang selama ini hanya diperoleh anak-anak yang mampu.Sedangkan Program seratus guru les privat dan ngaji bertujuan untuk membina para lulusan SMA sederajat yang lemah secara ekonomi, namun punya kemampuan yang baik secara akademik.Program seratus guru les privat dan ngaji ini dilakukan dengan memberikan pembinaan dan pelatihan pedagogik dan pembinaan Baca dan Tulis Al-Qur'an (BTQ).Pembinaan dan pelatihan ini diharapkan bisa menjadi 
pengalaman dan bekal yang cukup kepada mereka sebelum disalurkan menjadi guru les privat ngaji.

Sedangkan langkah-langkah yang dilakukan oleh Rumah Cerdas Al Farisi dalam melaksanakan program tersebut adalah:

1. Membentuk tim yang terdiri dari beberapa staf Rumah Cerdas Al Farisi yang diberi tugas untuk mensosialisasikan program

2. Melakukan sosialisasi program kepada masyarakat seperti di majelis-majelis taklim, pertemuan ibu-ibu PKK, dan sekolah-sekolah, serta mensosialisasikan program melalui media sosial.

3. Setelah melakukan sosialisasi program, sedikit demi sedikit tim menyiapkan kegiatan, kegiatan yang dijalankan meliputi kegiatan sosial, dan keagamaan, misalnya bimbingan belajar gratis bagi siswa SD dan SMP, buka bersama gratis di bulan suci Ramadhan, dan mengadakan daurah menghafal alQur'an.

4. Meningkatkan sdm dengan cara memberikan pembinaan dan pelatihan ilmu pedagogik dan Baca Tulis AlQur'an (BTQ). Selama pembinaan, siswa binaan melakukan praktek mengajar (microteaching) dihadapan siswa-siswi SD dan SMP yang mendapatkan bimbingan belajar gratis di Rumah Cerdas Al Farisi.

5. Menyalurkan siswa binaan menjadi guru les privat dan ngaji sesuai dengan permintaan masyarakat, dan setiap bulannya mereka mendapatkan gaji sesuai dengan ketentuan yang disepakati dengan masyarakat pengguna jasa les privat dan ngaji.

6. Tahapan akhir, mengadakan evaluasi setiap bulan. Evaluasi dilakukan tidak hanya dengan siswa binaan tapi juga dengan masyarakat pengguna jasa les privat dan ngaji. Dengan adanya evaluasi, diharapkan pembelajaran les privat dan ngaji bisa berjalan dengan baik.
Subjek dalam penelitian ini terdiri dari tiga unsur yaitu siswa yang menjadi binaan penguatan ekonomi di Rumah Cerdas $\mathrm{Al}$ Farisi, kepala Rumah Cerdas Al Farisi, dan masyarakat pengguna jasa les privat dan ngaji. Siswa lulusan SMA sederajat menjadi sumber utama dalam penelitian ini karena mereka yang merasakan langsung program pembinaan penguatan ekonomi di Rumah Cerdas Al Farisi. Pengurus Rumah Cerdas Al Farisi menjadi informan karena pengurus Rumah Cerdas Al Farisi yang memiliki wewenang untuk menjalankan program kegiatan, mengatur dan menentukan penempatan program dan menginisiai program. Sedangkan masyarakat pengguna jasa les privat dan ngaji menjadi informan karena mereka yang merasakan langsung hasil pembinaan penguatan ekonomi di Rumah Cerdas $\mathrm{Al}$ Farisi melalui program 100 guru les prifat dan ngaji.

Hasil wawancara yang dilakukan oleh peneliti dengan siswa yang menjadi binaan di Rumah Cerdas Al Farisi, menyebutkan bahwa semua siswa binaan menyatakan sangat senang mengikuti pembinaan di Rumah Cerdas Al Farisi dengan dua programnya. Misalnya, Nur Fatimatus Sholikh mengatakan bahwa setelah mengikuti pembinaan, dan disalurkan menjadi guru les privat dan ngaji, dia merasa lebih bersemangat dalam menjalani kehidupannya. Hasil dari menjadi guru les privat dan ngaji, bisa dia gunakan untuk mencukupi kebutuhan ekonominya, bahkan dari hasil les prifat dan ngaji dia bisa melanjutkan ke bangku kuliah dengan biaya mandiri. Saat ini dia sedang kuliah di Sekolah Tinggi Ilmu Tarbiyah Raden Wijaya Mojokerto. Demikian juga dengan siswa binaan yang lain yaitu Isnun Lailatul Qomariyah, Laura Golfena Kasiadi, Yuni Maulidiyah, Fitri Indah Yani dan Nur Aini. Mereka semua merasa senang dengan adanya pembinaan di Rumah Cerdas Al Farisi, program seratus guru les privat dan ngaji tidak hanya sebagai tempat mengasah skill, tapi juga sebagai bekalsebelum 
disalurkan menjadi guru les privat dan ngaji, dan hasil dari les privat dan ngaji banyak membantu perekonomian keluarga mereka, dan yang terpenting mereka bisa melanjutkan ke bangku kuliah dengan biaya mandiri.

Indikator Keberhasilan program pembinaan di Rumah Cerdas Al Farisi Mojokerto bisa dilihat dari semakin meningkatnya daya konsumsi masyarakat binaan. Ada tiga indikator yang mencadi acuan keberhasilan program Rumah Cerdas Al Farisi, Yaitu 1) Indikator pemenuhan makan dan minum; 2) Indikator pemenuhan pendidikan; dan 3) Indikator pemenuhan kendaraan. Ketiga indikator tersebut bisa dilihat dalam uraian Tabel 1, 2, dan 3 berikut ini:

Tabel 1. Pemenuhan Makan dan Minum

\begin{tabular}{|c|l|l|l|l|}
\hline \multirow{2}{*}{$\begin{array}{l}\text { N } \\
\text { o }\end{array}$} & Informan & \multicolumn{2}{|c|}{$\begin{array}{l}\text { Pemenuhan Makan } \\
\text { dan Minum }\end{array}$} & \multirow{2}{*}{ Keterangan } \\
\cline { 2 - 4 } & Sebelum & Sesudah & \\
\hline 1 & $\begin{array}{l}\text { Nur } \\
\text { Fatimatus } \\
\text { Sholikh }\end{array}$ & Kurang & Mampu & Terberdaya \\
\hline 2 & $\begin{array}{l}\text { Isnun } \\
\text { Lailatul } \\
\text { Qomariyah }\end{array}$ & Mampu & Mampu & Terberdaya \\
\hline 3 & $\begin{array}{l}\text { Laura } \\
\text { Golfena } \\
\text { Kasiadi }\end{array}$ & Kurang & Mampu & Terberdaya \\
\hline 4 & Nur Aini & Mampu & Mampu & Terberdaya \\
\hline 5 & $\begin{array}{l}\text { Yuni } \\
\text { Maulidiyah }\end{array}$ & Kurang & Mampu & Terberdaya \\
\hline 6 & $\begin{array}{l}\text { Fitri Indah } \\
\text { Yani }\end{array}$ & Kurang & Mampu & Terberdaya \\
\hline
\end{tabular}

Dari data tabel di atas informan kedua dan keempat yaitu Isnun lailatul Qomariyah dan Nur Aini sebelum mengikuti pembinaan di rumah Cerdas Al Farisi sudah "mampu" memenuhi kebutuhan makan mereka, faktor yang menjadi penyebab mampunya mereka karena sebelum mengikuti program pemberdayaan mereka sudah bekerja yaitu mengajar di TK (taman kanak kanak), tepatnya di Taman kanak-kanak Litle Camel Sooko Mojokerto, sehingga dari hasil mengajar sedikit banyak bisa memenuhi kebutuhan sehari-hari mereka.

Sedangkan informan pertama dan ketiga, kelima dan keenam yaitu Nur
Fatimatus Sholihah, Laura Golfena Kasiadi, Yuni Maulidiyah, dan Fitri Indah Yani sebelum mengikuti program pembinaan di Rumah Cerdas Al Farisi masih belum mampu memenuhi kebutuhan makan dan minum secara mandiri, ketidakmampuan tersebut dari kurangnya pemenuhan makan dan minum, disebabkan mereka belum mendapatkan pekerjaan. Setelah mengikuti pembinaan di Rumah Cerdas Al Farisi melalui program 100 guru les privat dan ngaji dan disalurkan menjadi guru les privat dan ngaji, mereka mampu memenuhi kebutuhan makan dan minum secara mandiri.

Tabel 2. Pemenuhan Pendidikan

\begin{tabular}{|c|l|l|l|l|}
\hline \multirow{2}{*}{$\begin{array}{l}\text { N } \\
\text { o }\end{array}$} & Informan & \multicolumn{2}{|c|}{$\begin{array}{c}\text { Pemenuhan } \\
\text { Pendidikan }\end{array}$} & \multirow{2}{*}{ Keterangan } \\
\cline { 2 - 5 } & Sebelum & Sesudah & \\
\hline 1 & $\begin{array}{l}\text { Nur } \\
\text { Fatimatus } \\
\text { Sholikh }\end{array}$ & SMA & Sarjana & Meningkat \\
\hline 2 & $\begin{array}{l}\text { Isnun } \\
\text { Lailatul } \\
\text { Qomariyah }\end{array}$ & SMA & Sarjana & Meningkat \\
\hline 3 & $\begin{array}{l}\text { Laura } \\
\text { Golfena } \\
\text { Kasiadi }\end{array}$ & SMA & SMA & Tetap \\
\hline 4 & Nur Aini & SMA & Sarjana & Meningkat \\
\hline 5 & $\begin{array}{l}\text { Yuni } \\
\text { Maulidiyah }\end{array}$ & SMA & SMA & Tetap \\
\hline 6 & $\begin{array}{l}\text { Fitri Indah } \\
\text { Yani }\end{array}$ & SMA & Sarjana & Meningkat \\
\hline
\end{tabular}

Dari data Tabel 2 di atas, informan pertama, kedua, keempat dan keenam sebelum mendapatkan pembinaan penguatan ekonomi di Rumah Cerdas Al Farisi Mojokerto melalui program 100 guru les privat dan ngaji, pemenuhan pendidikan mereka meningkat. Hal terbukti dengan masuknya mereka ke perguruan tinggi.Nur Fatimatus Sholikh melanjutkan kuliah di STIT Raden Wijaya Mojokerto, Isnun Lailatul Qomariyah melanjutkan Kuliah di STIT Raden Wijaya Mojokerto, Nur Aini melanjutkan kuliah di STIT Raden Wijaya Mojokerto, dan Fitri Indah Yani Melanjutkan kuliah di Sekolah Tinggi Urwatul Wustqa Jombang.Sedangkan informan ketiga dan kelima sebelum mendapatkan program penguatan ekonomi 
adalah "tetap", tidak ada perubahan peningkatan pendidikan.Faktor keluarga menjadi alasan utama tidak terjadinya peningkatan pendidikan, karena informan ketiga dan kelima merupakan tulang punggung keluarga, sehingga hasil dari les privat dan ngaji mereka alokasikan untuk mencukupi kebutuhan keluarga mereka.

Tabel 3. Pemenuhan Kendaraan

\begin{tabular}{|c|l|l|l|l|}
\hline \multirow{2}{*}{ No } & Informan & \multicolumn{2}{|c|}{$\begin{array}{l}\text { Pemenuhan } \\
\text { Kendaraan }\end{array}$} & \multirow{2}{*}{$\begin{array}{c}\text { Keterang } \\
\text { an }\end{array}$} \\
\cline { 3 - 4 } 1 & $\begin{array}{l}\text { Nur } \\
\text { Fatimatus } \\
\text { Sholikh }\end{array}$ & Memiliki & memiliki & $\begin{array}{l}\text { Tidak } \\
\text { berdaya }\end{array}$ \\
\hline 2 & $\begin{array}{l}\text { Isnun } \\
\text { Lailatul } \\
\text { Qomariya } \\
\text { h }\end{array}$ & Memiliki & $\begin{array}{l}\text { Memilik } \\
\text { i }\end{array}$ & $\begin{array}{l}\text { Tidak } \\
\text { berdaya }\end{array}$ \\
\hline 3 & $\begin{array}{l}\text { Laura } \\
\text { Golfena } \\
\text { Kasiadi }\end{array}$ & $\begin{array}{l}\text { Tidak } \\
\text { memiliki }\end{array}$ & $\begin{array}{l}\text { Memilik } \\
\text { i }\end{array}$ & Mampu \\
\hline 4 & Nur Aini & $\begin{array}{l}\text { Tidak } \\
\text { memiliki }\end{array}$ & $\begin{array}{l}\text { Memilik } \\
\text { i }\end{array}$ & Mampu \\
\hline 5 & $\begin{array}{l}\text { Yuni } \\
\text { Maulidiya } \\
\text { h }\end{array}$ & $\begin{array}{l}\text { Tidak } \\
\text { memiliki }\end{array}$ & $\begin{array}{l}\text { Memilik } \\
\text { i }\end{array}$ & Mampu \\
\hline 6 & $\begin{array}{l}\text { Fitri Indah } \\
\text { Yani }\end{array}$ & $\begin{array}{l}\text { Tidak } \\
\text { memiliki }\end{array}$ & $\begin{array}{l}\text { Memilik } \\
\text { i }\end{array}$ & Mampu \\
\hline
\end{tabular}

Dari Tabel 3 di atas, informan pertama dan kedua yaitu Nur Fatimatus Sholik dan Isnun Lailatul Qomariyah sebelum mendapatkan pembinaan penguatan ekonomi di Rumah Cerdas Al Farisi Mojokerto melalui program 100 Guru Les Privat dan ngaji sudah memiliki sepeda motor untuk beraktifitas, setelah mendapatkan pembinaan, keduanya ini masih tetap memiliki kendaraan bermotor untuk menunjang aktifitas kegiatan mereka. Sedangkan informan ketiga dan keempat yaitu Laura Golvena Kasiadi, Nur Aini, Yuni Maulidiyah, dan Fitri Indah Yani sebelum mendapatkan pembinaan penguatan ekonomi di Rumah Cerdas Al Farisi Mojokerto melalui program 100 Guru Les Privat dan ngaji tidak memiliki sepeda motor untuk beraktifitas, setelah mendapatkan pembinaan penguatan ekonomi, mereka bisa membeli kendaraan bermotor untuk menunjang aktifitas kegiatan mereka. Walaupun kendaraan bermotor tersebut mereka beli dengan sistem kredit.

\section{SIMPULAN}

Berdasarkan hasil dan pembahasan penelitian, dapat ditarik kesimpulan sebagaimana berikut: 1) Rumah Cerdas $\mathrm{Al}$ Farisi Mojokerto melalui pembinaan penguatan ekonomi melalui program 100 guru les privat dan ngaji, telah menjalankan program penguatan ekonomi melalui empat aspek yang sangat penting. Empat aspek tersebut adalah sosial, pendidikan, ekonomi dan sumber daya manusia. 2) Program pembinaan penguatan ekonomi di Rumah Cerdas Al Farisi melalui program 100 guru les privat dan ngaji mampu meningkatkan ekonomi masyarakat, khususnya siswa yang menjadi binaan. Hal tersebut dapat dilihat dari tiga indikator yang terpenuhi, yaitu indikator makan dan minum, indikator pendidikan, dan indikator kendaraan.

\section{DAFTAR PUSTAKA}

Andi, Rianto. (2013). Metode Penelitian Sosial dan Hukum. Jakarta: Granit.

Arikanto, Suharsimi, 2012. Prosedur Penelitian Suatu Pendekatan Praktek. Jakarta: Rineka Cipta.

Azwar, Saifuddin. (2015). Metode Penelitian. Yogyakarta: Pustaka Pelajar.

Bisri, Cik Hasan. (2014). Model Penelitian

Fiqih Jilid 1: Paradigma Penelitian Fiqih dan Fiqih Peneltian. Jakarta: PT. Raja Grafindo Persada.

El Wafa, Hosnu. (2014). Konsepsi Zakat Produktif dalam Pemikiran Syekh Muhammad Arsyad Al-Banjari (Studi terhadap kitab Sabil al-Muhtadin). Yogyakarta: UIN Sunan Kalijaga.

Ibrahim, M. Saad. (2011). Metodologi Penelitian Hukum Islam. Malang; Universitas Islam Negeri.

Ife, Jim. (2010). Community Development: Creating Community Alternatives, Vision, Analysis and Practice. Longman. Australia 
Moleong, Lexy J. (2014). Metodologi Penelitian Kualitatif. Bandung: PT. Remaja Rosda Karya.

Muhadjir, Noeng. (2010). Metodologi Penelitian Kualitatif. Yogyakarta: Rake Sarasin.

Nasution. (2010). Metode Research : Penelitian Ilmiah. Jakarta : Bumi Aksara.

Sujana, Nana. (2015). Proposal Penelitian Di Perguruan Tinggi. Bandung: Sinar Baru Algesindo.

Saefuddin, Ahmad M. (2013). Ekonomi dan Masyarakat dalam Perspektif Islam. Jakarta: CV Rajawali.

Sulistiyani, Ambar Teguh. (2011). Manajemen Sumber Daya Manusia, Graha Ilmu, Yogyakarta.

Soerkanto, Soejono. (2015). Penelitian Hukum Normatif. Jakarta: PT. Raja Grafindo Persada.

Songgono, Bambang. (2010). Metodologi Penelitian Hukum. Jakarta: PT. Raja Grafindo Persada.

http://mojokertokab.bps.go.id/index.php/ma ster Menu/3 (diakses 20 Agustus 2018). 